\title{
Belas Kasih Allah dalam Penerimaan Komuni Suci Bagi Orang dengan Retardasi Mental
}

\author{
Chosmas Christian Timur \\ Magister Teologi Universitas Sanata Dharma \\ ootchristian@yahoo.com
}

\begin{abstract}
People with mental retardation have limitations in intellectual and adaptive functioning. Intellectual functioning refers to general mental capacity such as learning, reasoning, problem solving, and so forth. Therefore, a person with mental retardation has limited understanding of the Body and Blood of Christ. Though it must be owned by the recipient of Holy Communion. This research aims to find pastoral solutions for people with mental retardation in the reception of Holy Communion. They have to obtain the divine grace of Christ through the sacraments if it is possible. This essay proposes a theological and pastoral discussion about this theme.
\end{abstract}

\section{Keywords:}

Retardasi Mental, Komuni Suci, Difabilitas, Ekaristi, Sakramen

\section{PENDAHULUAN}

Semakin hari, perhatian Gereja terhadap difabel dan berkebutuhan khusus semakin tampak. Perhatian ini terlihat dari sarana dan prasarana yang mendukung mobilitas, perhatian melalui paguyuban dan gerakan sosial serta pelayanan sakramen. Keuskupan - keuskupan di Indonesia mulai memberikan pelayanan sakramen inisiasi bagi difabel dan berkebutuhan khusus. Keuskupan Agung Semarang misalnya, sudah beberapa kali menyelenggarakan misa penerimaan sakramen inisiasi ini yang dipimpin Uskup Agung Semarang Mgr. Robertus Rubiyatmoko. Penerimaan sakramen inisiasi bagi difabel dan berkebutuhan khusus ini mendapatkan tanggapan yang positif khususnya bagi orangtua. Kerinduan orangtua untuk melihat anaknya menerima sakramen inisiasi terpancar dari wajah-wajah bahagia dan haru mereka. Dalam penerimaan sakramen inisiasi ini ada banyak kelonggaran yang diberikan sehingga persiapan untuk penerimaan sakramen inisiasi maupun persyaratannya juga 
disesuaikan dengan kemampuan difabel dan berkebutuhan khusus. Salah satu bentuk dari difabilitas atau berkebutuhan khusus adalah retardasi mental. Menurut Samuel A. Kirk, psikolog Amerika, pendidik dan peneliti disabilitas, retardasi mental bukanlah penyakit tetapi sebuah situasi. Situasi ini mengacu pada fungsi intelektual yang dimulai sejak masa perkembangan dan berkaitan dengan kemampuan pribadi dalam menyesuaikan diri. Retardasi mental ini juga disebabkan oleh banyak faktor dan memiliki beberapa tingkatan. ${ }^{1}$ Situasi ini menyebabkan orang dengan retardasi mental mengalami kesulitan dalam memahami sesuatu dan dalam bersosialisasi.

Perhatian kepada difabel dan umat berkebutuhan khusus ini dapat dilakukan dengan berbagai macam hal. Salah satu bentuk perhatian Gereja kepada umat berkebutuhan khusus, khususnya orang dengan retardasi mental, adalah melalui pelayanan sakramen yang masih memungkinkan untuk mereka terima. Ketika orang dengan difabel ini berada dalam satu lingkungan dan merasakan ikatan dengan orang-orang disekitarnya, menjadi hal yang normal untuknya apabila ia memiliki keinginan untuk menerima Komuni Suci. Keluarga dan katekis perlu membantu perkembangan keinginan ini, menjaganya dan merencanakan penerimaan komuni pertama selagi keinginan itu tumbuh. Seorang katekis yang mengerti akan memahami bahwa peristiwa ini akan lebih memberikan buah-buah baik setelah Komuni Pertama. ${ }^{2}$

Dalam penerimaan komuni suci ini penulis melihat ada beberapa permasalahan dalam penerimaan komuni suci bagi orang dengan retardasi mental. Permasalahan tersebut seperti penerima tidak mau menerima hosti yang diberikan, penerima tidak mau memakan hosti atau penerima yang tidak mau menelan hosti. Karena hosti yang sudah dikonsekrasi adalah tubuh Kristus yang harus dihormati maka dibutuhkan pemahaman yang cukup bagi seseorang untuk dapat meneri ma komuni suci. Permasalahan yang dihadapi orang dengan retardasi mental dalam menerima komuni tersebut membuat tidak nyaman orangtua ataupun pendamping. Namun lebih dari rasa tidak nyaman, situasi tersebut memunculkan pertanyaan sejauh mana orang dengan retardasi mental dapat menerima komuni suci? Maka penelitian ini akan menjawab pertanyaan tersebut. Bagaimanapun orang dengan retardasi mental juga merupakan bagian dari Gereja yang harus terakomodasi hak-haknya da-

1 Bdk. Noel A Kinsela, , B.A, S.T.L, Ph.D, Moral Orientation Of The Mentaly Retarded (Roma: Pontificia Universita Lateranense, 1976), hal. 2.

2 Joseph Bernardin, "The Sacraments and Developmentally Disabled Person", Origins: NC Documentary Service 15, no.47 (8 Mei 1986), hal. 78. 
lam Gereja. Penelitian ini dibutuhkan agar para imam dan para pendamping memiliki pegangan dalam pendampingan penerimaan komuni suci bagi orang dengan retardasi mental.

\section{METODE}

Metode yang digunakan adalah studi pustaka dan wawancara. Studi pustaka digunakan untuk mendapatkan acuan yang jelas tentang tema penulisan. Hasil wawancara digunakan sebagai pendukung untuk memperdalam pemahaman tentang tema dan mendapatkan pengalaman-pengalaman pendampingan terhadap orang dengan retardasi mental. Wawancara dilakukan terhadap orang dengan retardasi mental, guru sekolah luar biasa, imam dan biarawati pendamping difabel khususnya retardasi mental.

\section{HASIL DAN PEMBAHASAN}

Tuhan telah menciptakan manusia "menurut gambarnya" (Kej 26:27). Apakah dalam hal ini berarti manusia selalu ada dalam kesempurnaan? Penting untuk diingat bahwa ada kebaikan dan kejatuhan dalam penciptaan, suatu realitas yang diperoleh pada satu waktu yang bersamaan. Kedua hal ini mempengaruhi setiap individu, setiap aspek penciptaan dan pada satu waktu yang bersamaan. Oleh karena itu, tidak dapat dikatakan bahwa beberapa orang memiliki semua kebaikan ciptaan yang disediakan untuk diri mereka sendiri dan tidak dibebani oleh kejatuhan, sementara yang lain dibiarkan dengan semua kejatuhan dan tidak mendapat manfaat dari kebaikan. Kedua realitas ini berlaku bagi setiap pribadi manusia. ${ }^{3}$ Dalam hal ini selalu ada kelebihan dan kekurangan yang dimiliki oleh manusia.

Di dalam Kristus, Roh diberikan kepada semua orang. Semua orang harus berharap untuk menghasilkan buahnya dan memanifestasikan karunia Roh apa pun yang diberikan kepada mereka. Roh Kudus tidak membedabedakan orang. Roh Kudus membawa semua umat Allah ke dalam satu tubuh. Dimasukkannya semua manusia ke dalam komunitas inklusif umat Allah merupakan karya Roh. Kita harus mengharapkan Roh memberi rahmat dan memberdayakan difabel. Tujuan Roh adalah untuk membuat manusia seperti Kristus, bukan untuk memungkinkan manusia dapat melihat atau berjalan. ${ }^{4}$

Bdk. Vinay Samuel, "God, Humanity and Disability”, Transformation 15, no. 4 (1998), hal. 15.

4 Bdk. Chris Sudgen, "Biblical and Theological Reflections on Disability", Transformation 15, no. 4 (1998), hal. 28. 
Retardasi mental adalah tingkat fungsi intelektual yang secara signifikan berada di bawah rata-rata sebagaimana diukur oleh tes intelegensi ${ }^{5}$ yang dilaksanakan secara individual. Untuk diklasifikasikan sebagai orang yang mengalami retardasi mental, fungsi sosial dan intelektual seseorang harus rusak (lemah). Retardasi mental dilihat sebagai suatu kondisi kronis dan tidak dapat diubah yang dimulai sebelum usia 18 tahun. Bila fungsi intelektual jatuh ke tingkat retardasi sesudah usia 18 tahun, maka masalah tersebut diklasifikasikan sebagai dementia dan bukan retardasi mental. ${ }^{6}$

Retardasi mental merupakan gangguan yang ditandai oleh fungsi intelektual disertai keterbatasan fungsi adaptif sedikitnya dalam dua area kemampuan. Kemampuan tersebut antara lain komunikasi, perawatan diri, pemenuhan kebutuhan hidup. Selain itu keterbatasan juga dalam kemampuan sosial interpersonal, penggunaan sumber daya masyarakat, kemandirian, kemampuan fungsi akademik, pekerjaan, waktu luang, kesehatan, keamanan. ${ }^{7}$

Fungsi intelektual, disebut juga dengan kecerdasan, mengacu pada kapasitas mental umum, seperti belajar, penalaran, pemecahan masalah, dan sebagainya. Gangguan fungsi intelektual ini, dapat diukur melalui tes $\mathrm{IQ}^{8}$ (intelligence quotient) yang diberikan secara individual. Umumnya individu yang memiliki IQ 70-75 masuk dalam kategori retardasi mental. Gangguan kemampuan adaptif biasanya ditunjukkan pada individu dengan retardasi mental. Fungsi adaptif mengacu pada kemampuan individu dalam mengatasi tuntutan hidup umum dan kemampuan mereka dalam memenuhi standar kemerdekaan pribadi yang diharapkan dari seseorang. Standar kemerdekaan pribadi ini dalam kelompok usia tertentu, latar belakang sosial budaya dan aturan-aturan dalam masyarakat. Fungsi adaptif dapat dipengaruhi oleh berbagai faktor, antara lain pendidikan, motivasi, kepribadian, kesempatan dalam kehidupan sosial, gangguan mental dan kondisi yang berkaitan dengan retardasi mental. ${ }^{9}$

5 Kebanyakan peneliti sependapat bahwa intelegensi adalah seperangkat ciri-ciri khas dan kemampuan kognitif yang tidak dapat diamati secara langsung. Bdk. Yustinus Semiun, OFM, Kesehatan Mental 2 (Yogjakarta: Kanisius, 2006), hal. 238.

6 Bdk. Ibid., hal. 265.

7 Diagnostic and Statistical Manual IV-TR (DSM IV-TR, 2004).

8 Dalam skala Wechsler, skor IQ>130 : very superior, 120-129: superior , 110-119: rata-rata atas, 90-109: rata-rata, 80-89: rata-rata bawah, 70-79: lambat belajar (borderline), <70: mentaly retarded atau retardasi mental. IQ (Intelligence Quotient) adalah angka indeks tunggal yang menyatakan tingkat kecerdasan seseorang dibandingkan dengan orang lain dalam sampel yang standard. IQ itu cenderung stabil secara relatif. Bdk. Semiun, OFM, Kesehatan Mental, hal. 242.

9 Bdk. American Psyciatric Association, Diagnostic and Statistical Manual of Mental Disorder IV (Washington: American Psychiatric Press Inc, 1994), hal. 42. Selanjutnya disingkat DSM IV. 
Retardasi mental bukanlah suatu penyakit tetapi keterbatasan intelektual dan fungsi adaptif yang dapat disertai dengan atau tanpa gangguan jiwa ataupun gangguan fisik lainnya. Usia dan kemampuan tergantung pada etiologi dan keparahan dari keterbelakangan mental itu sendiri. Keterbelakangan mental yang disertai dengan sebuah sindrom dengan karakteristik fenotipe yang diketahui sejak awal - misalnya, down syndrom yang biasanya didiagnosis saat lahir - dapat menyebabkan retardasi mental yang berat. Sebaliknya, retardasi mental ringan diketahui setelah melihat perkembangan individu sampai dengan 18 tahun. ${ }^{10}$ Menurut Diagnostik and Statistical Manual of Mental Disorder IV (DSM IV), retardasi mental belum tentu merupakan gangguan seumur hidup. Individu dengan Retardasi Mental Ringan mengalami kegagalan dalam belajar akademik. Memberikan pelatihan yang tepat dan membantunya untuk mengembangkan keterampilan adaptif yang baik, memungkinkan orang dengan retardasi mental untuk tidak mengalami penurunan tingkatan retardasi mental. ${ }^{11}$

\section{Tingkatan Retardasi Mental}

Retardasi Mental memiliki empat tingkatan kemampuan berdasarkan IQ yang dimiliki. Empat tingkatan tersebut adalah mild mental retardation (retardasi mental ringan), moderate mental retardation (retardasi mental sedang), severe mental retardation (retardasi mental parah), dan profound mental retardation (retardasi mental mendalam atau sangat parah). Individu dengan mental retardasi ringan memiliki IQ 50-70. Tingkatan ini adalah kelompok terbesar dari orang dengan retardasi mental karena dimiliki oleh 85 persen orang dengan retardasi mental. ${ }^{12}$ Kemampuan berpikir "orang dengan retardasi mental ringan”, untuk usia pra sekolah, kemungkinan tidak terlihat memiliki perbedaan konseptual dengan anak-anak lain. Pada anak usia sekolah dan masa selanjutnya, mereka mengalami kesulitan dalam hal akademik termasuk di dalamnya membaca, menulis, menghitung, waktu, dan konsep mengenai uang. Pada usia dewasa mereka juga mengalami gangguan dalam hal berpikir (seperti merencanakan sesuatu, membuat strategi, membuat prioritas, penyesuaian diri), ingatanjangka pendek dan penggunaan kemampuan akademik. Orang dengan retardasi men-

\footnotetext{
${ }^{10}$ Bdk. Ibid., hal. 47.

11 Bdk. Ibid., hal. 47.

12 Charles Wenar, Patricia Kerig, Developmental Psychopathology From Infancy Through Andolescence Fourth Edition (New York: Mc Graw-Hill Higher Education, 2000), hal. 260.
} 
tal ringan membutuhkan bantuan agar setara dengan kemampuan yang dimiliki oleh individu seusianya. ${ }^{13}$

"Orang dengan retardasi mental sedang" mengalami ketertinggalan dari individu seusianya. Pada usia pra sekolah, kemampuan berbicara dan kemampuan pra akademik mereka lamban. Demikian pula pada masa sekolah, perkembangan orang dengan retardasi mental sedang dalam hal membaca, menulis, berhitung, pemahaman mengenai waktu dan uang, terlihat lamban dibandingkan dengan anak-anak lainnya. ${ }^{14}$ Orang dengan retardasi mental sedang yang berusia dewasa, perkembangan kemampuan akademik yang mereka miliki setara dengan pendidikan dasar sehingga dibutuhkan bantuan dalam semua hal yang berhubungan dengan pendidikan dan keterampilan pribadi. Pendampingan secara terus menerus dibutuhkan dalam keseharian mereka dan mungkin juga mengambil alih tanggung jawab yang dimiliki orang dengan. ${ }^{15}$

Pencapaian kemampuan konseptual "orang dengan retardasi mental parah" sangat terbatas. Individu yang mengalami tingkatan retardasi mental ini, memiliki sedikit pemahaman mengenai tulisan, bahasa ataupun pengetahuan mengenai angka, jumlah, waktu dan uang. Mereka membutuhkan bantuan untuk mengatasi permasalahan tersebut sepanjang hidupnya. "Orang dengan retardasi mental sangat parah" benar-benar tidak dapat mengembangkan kemampuan intelektual. Mereka hanya sedikit menunjukan perkembangan sensormotorik sehingga orang dengan dalam tingkatanini sangat membutuhkan perawatan. Oleh karena itu, dari sisi intelektual, orang dengan retardasi mental sangat parah tidak dapat diharapkan banyak mengerti mengenai apa yang disampaikan.

Retardasi mental belum tentu merupakan gangguan seumur hidup. Individu yang memiliki retardasi mental ringan pada usia sekolah dasar mengalami kegagalan dalam tugas-tugas belajar akademik. Dengan pelatihan dan kesempatan yang tepat, mengembangkan keterampilan adaptif yang baik di bidang lain membantu orang dengan retardasi mental untuk tidak mengalami penurunan tingkat retardasi mental. Menurut tingkatan kemampuannya, orang dengan retardasi mental dapat dilatih untuk memahami sesuatu hal atau diajarkan ketrampilan-ketrampilan yang dapat berguna dalam hidupnya.

\footnotetext{
${ }^{13}$ American Psyciatric Association, Diagnostic and Statistical Manual of Mental Disorder V (Washington: American Psychiatric Publishing, 2013), hal. 34.

${ }^{14}$ Bdk. Ibid., hal. 35.

${ }^{15}$ Bdk. Ibid., hal. 35.
} 


\section{Makna Komuni Suci}

Communio atau komuni mendapat arti: kesatuan atau persatuan dengan Kristus melalui perjamuan Ekaristi mengikuti Sabda Tuhan Yesus sendiri, "Siapa yang makan daging-Ku dan minum darah-Ku, tinggal di dalam Aku dan Aku di dalam dia" (Yoh 6;56). Pada praktek Gereja abad-abad pertama, komuni diterimakan langsung sesudah kata "Amin" dari umat pada akhir doxologi penutup. Namun, dalam perkembangan kemudian, antara Doa Syukur Agung dan penerimaan komuni sendiri disisipi macam-macam doa, seperti Bapa Kami, Embolisme ${ }^{16}$ dan sebagainya, supaya umat lebih pantas menyambut Kristus yang hadir dalam rupa roti dan anggur itu. ${ }^{17}$

Melalui komuni umat beriman berpastisipasi dalam karya penebusan yang dilakukan Kristus. Dalam Doa Syukur Agung makna karya penebusan ini dikenangkan. Melalui pemecahan roti dan komuni, umat beriman meskipun banyak, disatukan karena menyambut Tubuh dan Darah Kristus yang satu, sama seperti dahulu para rasul menerimanya dari tangan Kristus sendiri (PUMR 72).

Mengenai partisipasi umat dalam penerimaan komuni ini, Sacrosanctum Concilium art. 55 menjelaskan bahwa dengan menerima Tubuh Kristus, partisipasi umat dalam Misa lebih sempurna. Dengan menerima hosti yang sudah dikonsekrasi, umat beriman bersatu dengan penebusan Kristus melalui Tubuh dan Darah Kristus yang diterimanya. Umat beriman juga berpartisipasi dalam persatuan dengan Tubuh Mistik Kristus yaitu Gereja. Sacrosanctum Concilium art. 26 menyatakan bahwa "Upacara-upacara Liturgi menyangkut seluruh Tubuh Gereja dan menampakkan serta mempengaruhinya; sedangkan masing-masing anggota disentuhnya secara berlain-lainan, menurut keanekaan tingkatan, tugas serta keikutsertaan aktual mereka". Oleh karena itu hendaknya umat selalu mempersiapkan diri dan membuat dirinya layak untuk dapat me-

${ }^{16}$ Dalam doa Tuhan, Bapa Kami, umat beriman mohon rezeki sehari-hari. Bagi umat Kristen rezeki sehari-hari ini terutama adalah roti Ekaristi. Umat juga memohon pengampunan dosa, supaya anugerah kudus itu diberikan kepada umat yang kudus. Imam mengajak jemaat untuk berdoa, dan seluruh umat beriman membawakan Bapa Kami bersama-sama dengan iman. Kemudian imam sendirian mengucapkan embolisme, yang diakhiri oleh jemaat dengan doksologi. Embolisme itu menguraikan isi permohonan terakhir dalam Bapa Kami dan memohon agar seluruh umat dibebaskan dari segala kejahatan (PUMR 81).

${ }_{17}$ Bdk. E. Martasudjita, Pr, Ekaristi. Tinjauan Teologis, Liturgis dan Pastoral (Yogyakarta: Kanisius, 2005), hal. 197. 
nerima Tubuh dan Darah-Nya.

Penerimaan Komuni selalu harus dilihat dalam kesatuan dengan perayaan Ekaristi. Sebab, Komuni merupakan bagian tidak terpisahkan dari perayaan Ekaristi. Komuni merupakan partisipasi umat beriman dalam misteri karya penyelamatan Allah yang dikenangkan dan didoakan dalam Doa Syukur Agung. Dengan demikian, penerimaan komuni selalu merupakan tanggapan dan ungkapan umat beriman dalam mengambil bagian dalam Misteri Paskah yang dihadirkan dalam perayaan Ekaristi. Dari segi ini maka penerimaan komuni di luar perayaan Ekaristi tidaklah ideal. ${ }^{18}$ Akan tetapi dengan pertimbangan prinsip pastoral dan penggembalaan umat, penerimaan Komuni di luar misa tetap dimungkinkan dan diperbolehkan. Penerimaan komuni di luar misa memang bisa dilihat sebagai kerinduan akan perayaan Ekaristi. Oleh karena itu, pemimpin liturgi sabda di luar perayaan Ekaristi harus senantiasa mengingatkan kesatuan tak terpisahkan antara perayaan Ekaristi dan penerimaan komuni di luar misa itu. ${ }^{19}$

\section{Ketentuan Penerimaan Komuni Suci}

Setiap umat beriman berhak menerima Komuni Suci. Akan tetapi , Gereja memberikan ketentuan - ketentuan yang mengatur penerimaan Komuni Suci. Ketentuan ini tidak hanya dalam cara menerimanya tetapi menyangkut juga siapa yang dapat menerimanya. Dalam pembahasan mengenai tinjauan yuridis ini, penulis akan menjelaskan mengenai ketentuan - ketentuan yang berkaitan dengan penerimaan Komuni Suci.

\section{Penerima Komuni Suci}

Sangat dianjurkan agar umat beriman menerima komuni suci dalam perayaan Ekaristi itu sendiri; akan tetapi mereka yang meminta atas alasan yang wajar di luar Misa hendaknya dilayani, dengan mengindahkan ritus liturgi (KHK Kan. 918). Akan tetapi, Gereja sudah menetapkan norma-norma yang tujuannya ialah partisipasi yang sering dan berdayaguna dalam Perjamuan Ekaristi. Norma-norma itu sekaligus menentukan kondisi dan situasi obyektif bila komuni tidak boleh diterimakan (bdk RC 82).

\footnotetext{
18 Bdk. Ibid., hal. 300.

19 Bdk. Ibid., hal. 301.
} 
Penerimaan komuni ini dapat dilakukan oleh semua orang yang sudah dibaptis akan tetapi orang tersebut tidak dilarang oleh hukum yang termuat dalam Kitab Hukum Kanonik (bdk. KHK Kan. 92). Sesudah hukuman itu dijatuhkan atau dinyatakan, mereka yang terkena ekskomunikasi ${ }^{20}$ dan interdik ${ }^{21}$, dilarang untuk menerima Komuni. Begitu pun dengan orang lain yang berkeras hati membandel dalam dosa berat yang nyata (bdk. KHK Kan. 915).

Kebiasaan Gereja sejak dahulu kala menunjukkan bahwa setiap orang harus memeriksa batinnya dengan mendalam dan bahwa setiap orang yang sadar berdosa berat, tanpa terlebih dahulu menerima sakramen pengakuan, jangan merayakan Misa atau menerima Tubuh Tuhan, kecuali ada alasan berat serta tiada kesempatan mengaku; dalam hal demikian hendaknya ia ingat bahwa ia wajib membuat tobat sempurna, yang mengandung niat untuk mengaku sesegera mungkin (bdk. KHK Kan. 916; RC. 81).

Penerimaan Komuni Suci merupakan kesatuan dengan Ekaristi oleh karena itu umat beriman menerima komuni dalam perayaan tersebut. Akan tetapi apabila ada alasan lain yang wajar yang menyebabkan umat harus menerima komuni di luar Ekaristi maka hendaknya dilayani dengan mengindahkan ritus liturgi (bdk. KHK Kan. 918). Sebagai contoh, orang yang berusia lanjut atau sedang sakit.

Persiapan yang dapat dilakukan sebelum menyambut Komuni Suci adalah hendaknya orang berpantang makanan dan minuman sekurang-kurangnya satu jam, terkecuali air semata-mata dan obat-obatan. Tetapi, imam yang pada hari yang sama merayakan Ekaristi dua atau tiga kali boleh makan sebelum Ekaristi kedua atau ketiga. Aturan ini tidak mengikat pada mereka yang lanjut usia, sakit, dan berada dalam perawatan (bdk. KHK Kan. 919).

Kanon dalam Kitab Hukum Kanonik tersebut menunjukkan bahwa tidak semua orang Katolik dapat menerima komuni suci. Mereka yang akan menerima komuni juga diberi persiapan yang cukup. Persiapan tersebut berupa pelajaran komuni pertama. Dalam kurun waktu tertentu, seorang katekis akan mendampingi dan memberikan pengajaran bagi peserta komuni pertama.

Untuk dapat menerima komuni, anak-anak harus sudah dapat menggunakan akal budinya dan memiliki cukup pengertian dan telah dipersiapkan dengan

\footnotetext{
${ }^{20}$ Di luar communio Gereja Katolik.
}

${ }^{21}$ Sanksi karena hukuman pidana. 
seksama sehingga mereka dapat memahami misteri Ekaristi dan mampu menyambut komuni dengan iman dan hormat (bdk. KHK Kan. 914). ${ }^{22}$ Pengawasan akan hal tersebut dilakukan oleh pastor paroki. Selain itu dalam kanon ini juga dikatakan bahwa sudah menjadi tugas orangtua serta mereka yang menggantikan kedudukan orangtua dan juga pastor paroki untuk mengusahakan agar anak-anak yang sudah dapat menggunakan akal budi dipersiapkan untuk menerima komuni pertama.

Dalam Ketentuan Pastoral Keuskupan Regio Jawa, Pasal 85 no.2 tentang Komuni Pertama dinyatakan:

Yang dapat menerima komuni pertama adalah anak katolik yang memiliki pemahaman cukup, telah dipersiapkan dengan saksama sehingga dapat memahami misteri Kristus sesuai dengan daya-tangkap mereka, dan mampu menyambut Tubuh Tuhan dengan iman dan khidmat, serta sedapat mungkin telah menerima Sakramen Tobat. Demi pertimbangan pastoral, komuni pertama ini diterimakan pada anak berusia 9 tahun.

Gereja dapat bekerjasama dengan orangtua dalam memperhatikan usia penerima Komuni pertama ini sehingga anak-anak yang sudah memenuhi usia yang dibutuhkan dalam Komuni pertama, dapat dipersiapkan.

Peserta persiapan Komuni Pertama adalah mereka yang dianggap sudah mampu memahami misteri Kristus dan menyambut Tubuh Kristus dengan iman dan khidmat (bdk. KHK Kan. 913), kecuali ada kasus khusus yang telah direkomendasikan oleh pastor paroki. Berdasarkan Ensiklik Quam Singulari, usia anak yang dapat menerima Komuni Suci adalah anak berusia 7 tahun. Pada usia 7 tahun, anak dianggap sudah dapat menggunakan akal budinya. ${ }^{23}$ Persiapan Komuni Pertama ini berlangsung minimal 12 kali pertemuan, belum termasuk latihan mengaku dosa dan pelaksanaaan mengaku dosa. Kecuali itu, sebelum menerima Komuni Pertama, sebaiknya ada saat untuk latihan bersama dengan peserta dan orangtuanya.

\section{Penerapan Ketentuan Gereja tentang Komuni Suci bagi Orang dengan Retardasi Mental}

Penerapan Kitab Hukum Kanonik tentang Komuni Suci bagi orang dengan retardasi mental ini memang menjadi suatu permasalahan yang membuat ben-

${ }^{22}$ Bdk. Martasudjita, Pr, Ekaristi, hal. 399. 
turan antara mengikuti hukum yang ada dengan keinginan memberikan pelayanan iman bagi mereka. Bukankan setiap orang yang sudah dibabtis dan tidak mendapatkan halangan secara hukum Gereja mempunyai hak untuk menerima komuni? Namun jawaban pertanyaan tersebut menjadi dilema karena dalam hukum disinggung mengenai kemampuan pemahaman akan misteri Kristus (KHK Kan. 913). ${ }^{24}$ Sedangkan orang dengan retardasi mental sering dilihat kurang memiliki kemampuan pemahaman yang baik.

Mengenai penerimaan komuni suci bagi orang dengan retardasi mental ini, ada sebuah pandangan dari Francis Jeremiah Connell dan Gerard Breitenbeck. Kedua Pastor ini mempunyai perhatian khusus bagi orang dengan retardasi mental dan menyampaikan tentang kemungkinan penerimaan Komuni Suci bagi orang dengan retardasi mental. Mereka memandang kanon dalam Kitab Hukum Kanonik mengenai Komuni Suci secara lebih kooperatif.

Paus Pius X dalam Ensiklik Quam Singulari25 (8 Agustus 1910), menyebutkan tentang kemampuan dalam penggunaan akal budi bagi penerima komuni. Selanjutnya dikatakan bahwa untuk penerima komuni pertama tidak perlu memiliki pemahaman yang sempurna dan mendalam mengenai ajaran Kristiani karena seiring bertumbuhnya usia dan kecerdasan seseorang, pemahaman ini akan terus berkembang. ${ }^{26}$

Niat yang benar untuk mendekati meja kudus adalah mereka yang dengan tulus tanpa kesombongan, bukan melulu sebuah rutinitas atau demi mendapatkan penghormatan dari orang lain tetapi dengan tujuan untuk menyenangkan Allah, bersatu lebih erat dengan Allah merasakan cintaNya dan mendapatkan kesembuhan untuk kelemahan dan kekurangannya. Gerard Breitenbeck menuliskan permasalahan tentang niat mengikuti Ekaristi ini dengan menanyakan kepada anak mengapa ia ingin mengikuti Ekaristi. Jika anak (retardasi mental) mengatakan "untuk menerima Yesus", dia bukanlah orang yang hanya melakukan sebuah rutinitas yang berbeda. Anak ini juga

${ }^{23}$ Bdk. Bernadeta M Droste"dc" Gloria, Quam Singulari (Ende: Yayasan Pustaka Nusatama, 2011), hal. 10.

${ }^{24}$ KHK Kan. 913. 1 “Agar Ekaristi Maha Kudus dapat diterimakan kepada anak-anak, dituntut bahwa mereka memiliki pemahaman cukup dan telah dipersiapkan dengan seksama,sehingga dapat memahami misteri Kristus sesuai dengan daya-tangkap mereka dan mampu menyambut Tubuh Tuhan dengan iman dan khidmat".

${ }^{25}$ Ensiklik Paus mengenai penerimaan Komuni Pertama.

${ }^{26}$ Bdk. Kinsela, Moral Orientation, hal. 82. 
tidak sedang melakukan sebuah kesombongan atau mendapatkan rasa hormat dari orang lain. Anak tersebut mengikuti Ekaristi untuk bersatu dengan Yesus yang mengasihi mereka. ${ }^{27}$

Dalam pembahasan Breitenbeck dan Connel ini tingkatan retardasi mental terbagi dalam tiga tingkat, yaitu Low Grade, Middle Grade dan High Grades. Menurut Breitenbeck untuk tingkatan Low Grede tidak akan mampu untuk memahami persyaratan komuni pertama karena hanya memiliki kemampuan pemahaman yang sangat kecil. Sedangkan Fr. Connel mengatakan bahwa Low Grade harus dikecualikan dari penerimaan Komuni Suci, tetapi aturan yang sama ini tidak harus diterapkan untuk Middle dan High Grade. ${ }^{28}$ Pembagian tingkatan retardasi mental tersebut berbeda dengan tingkatan retardasi mental dalam DSM IV. Dalam tingkatan retardasi mental Connel dan Breitenbeck, retardasi mental parah dan sangat parah masuk dalam kategori low grade.

Connel mengacu pada Ensiklik Quam Singularis yang memberikan kelonggaran kepada anak-anak untuk tidak perlu memiliki seluruh persyaratan penerimaan komuni suci, tetapi menggunakan penilaian dari pemahaman yang dirasa cukup memberikan alasan untuk menerima Komuni Suci. Para pendamping rohani anak dengan retardasi mental tidak boleh tergesa-gesa untuk memutuskan bahwa anak tersebut tidak dapat menerima Komuni Suci. Connel mengatakan bahwa anak dengan retardasi mental yang dapat menyampaikan pemikiran mereka walaupun sederhana dan kadang membingungkan, kemungkinan dapat menerima Komuni Suci dengan pendampingan dan pengajaran yang memadai..$^{29}$

Mengenai kemampuan orang dengan retardasi mental dalam pemahaman akan sesuatu hal, Breitenbeck mengatakan bahwa pada suatu ketika orang dengan retardasi mental memiliki kesulitan besar dalam mengekspresikan dirinya dengan jelas atau dalam mengomunikasikan ide-idenya secara lisan. Hal ini bukan berarti bahwa orang dengan retardasi mental tidak mengerti penyampaian secara lisan. Cara tersebut bukan satu-satunya cara berkomunikasi yang dapat membuat anak mengerti atau memahami. Kinsela mengatakan anak dengan retardasi mental sering mengerti, tetapi tidak dapat mengkomunikasikan pemahaman ini dalam ekspresi verbal. Kesulitan ini bisa

\footnotetext{
27 Bdk. Ibid., hal. 82.

${ }^{28}$ Bdk. Ibid., hal. 83.

${ }^{29}$ Bdk. Ibid., hal. 84.
} 
diatasi dengan beberapa cara. Pertama, memungkinkan anak untuk mengidentifikasi orang atau ide dari gambar. Kedua, mengizinkan anak untuk menjawab pertanyaan dengan menggerakkan kepala atau dengan berekspresi yang lain. ${ }^{30}$ Breitenbeck juga mengatakan bahwa dalam menilai pemahaman atau pengertian dari orang dengan retardasi mental, harus selalu dilihat seluruh kondisinya.

Keinginan orang dengan retardasi mental untuk menerima Komuni Suci mungkin diungkapkan dalam pola yang agak tidak biasa. Akan tetapi, apapun itu, baik orang dengan retardasi mental tingkatan Middle Grade dan High Grade dengan pelatihan yang tepat dapat mewujudkan keinginan mereka untuk menerima Komuni Suci.

Sehubungan dengan pemahaman akan dosa bagi orang dengan retardasi mental yang akan mempengaruhi penerimaan Komuni Suci, Connel berpendapat bahwa ada orang dengan retardasi mental yang tidak punya pemahaman yang cukup mengenai dosa, paling tidak dosa berat. Mereka juga tidak tepat untuk menjadi subjek yang bersalah karena melakukan dosa berat. Akan tetapi, mereka memiliki pemahaman yang cukup tentang Tuhan dan hukum kasihNya. Connel berpendapat bahwa orang dengan retardasi mental tidak mampu melakukan dosa tetapi mereka bisa mendapatkan rahmat. ${ }^{31}$

Para pendamping yang mendampingi anak orang dengan retardasi mental yang akan menerima KomuniSuci harus siap untuk memberikan pendampingan yang panjang dan memiliki kesabaran untuk mengulang-ulang pelajaran sampai anak ini memiliki kemampuan untuk memahami Sakramen Maha Kudus walaupun sederhana. Ketika proses ini dapat berlangsung dengan baik, banyak anak yang pada awalnya seperti tidak memiliki kemampuan minimal untuk menerima Komuni Suci akhirnya mampu memahami dan menerima Komuni Suci.

Kinsela berpendapat bahwa poin penting yang perlu dipahami oleh seorang imam adalah bahwa orang dengan retardasi mental juga merupakan umatnya seperti juga umat normal lainnya. Oleh karena itu, imam harus memberikan pelayanan kepada mereka tidak hanya sebatas perhatian kepada orangtuanya. Kita tahu bahwa Gereja tidak meragukan bahwa saluran rahmat harus diberikan kepada setiap jiwa tidak hanya bagi individu yang normal. Anugerah rahmat

\footnotetext{
${ }^{30}$ Bdk. Ibid., hal. 83.

${ }^{31}$ Bdk. Ibid.
} 
ini dibagikan kepada semua orang melalui sakramen-sakramen sejauh memungkinkan bagi penerimanya. ${ }^{32}$ Dengan demikian dari uraian mengenai pandangan penerimaan Komuni Suci ini, dapat dikatakan bahwa masih ada kemung kinan bagi orang dengan retardasi mental untuk menerima Komuni Suci walaupun harus melihat kondisinya dan harus dengan pendampingan yang intensif.

\section{Kasih Allah bagi Difabel dan Umat Berkebutuhan Khusus}

Orang dengan retardasi mental adalah bagian dari Gereja yang harus mendapatkan perhatian. Dalam Majalah Hidup edisi ke 27 tahun ke-70 disampaikan bahwa selama Tahun Suci Kerahiman Allah, Paus Fransiskus juga memberikan kesempatan perayaan Yubelium bagi orang sakit dan kaum difabel. Rangkaian perayaan Yubelium digelar di Vatikan. Bahkan Bapa Suci pun ikut hadir dalam Kongres disabilitas yang diprakarsai para Uskup Italia. Perhatian Tahta Suci terhadap Umat Berkebutuhan Khusus (UBK) ini sungguh menggetarkan. Lapangan St. Petrus Vatikan penuh ribuan umat dalam Misa Yubelium bagi orang sakit dan kaum difabel. Paus mengajak semua pihak dalam Gereja untuk memperbarui komitmen bersama dalam pelayanan terhadap UBK. Gereja dalam level terkecil di paroki mestinya menjamin bahwa sesama yang berkebutuhan khusus diterima menjadi bagian di dalamnya, juga oleh asosiasi dan organisasi, serta gerakan Katolik lainnya. Seruan Bapa Suci ini seolah menegaskan kembali iman Gereja akan Yesus Kristus, Sang Tabib Sejati. Menurut Paus, Yesus adalah tabib yang menerima siapapun yang datang kepadaNya. Gereja sudah semestinya menerima dan melayani UBK dengan cinta seperti Yesus. ${ }^{33}$

Dalam 1Kor 12:22 dikatakan, "Malahan justru anggota-anggota tubuh yang nampaknya paling lemah, yang paling dibutuhkan". Kemudian dalam 2Kor 12:9, Tuhan mengatakan, "Cukuplah kasih karunia-Ku bagimu, sebab justru dalam kelemahanlah kuasa-Ku menjadi sempurna. Sebab itu terlebih aku suka bermegah atas kelemahanKu, supaya kuasa Kristus turun menaungi aku." Dari ayat tersebut terlihat bagaimana Allah tidak meniadakan kelemahan tetapi justru menempatkan kelemahan tersebut untuk dapat mencapai kesempurnaan.

\footnotetext{
${ }^{32}$ Bdk. Ibid., hal. 93.

${ }^{33}$ R.B.E. Agung Nugroho, “UBK Bagian Gereja”, Hidup, 3 Juli 2016, hal. 10.
} 
Pertanyaan yang kemudian muncul dari ayat tersebut apabila dikaitkan dengan orang dengan disabilitas adalah apakah Gereja tidak akan memiliki keterbukaan untuk mereka, yang juga merupakan bagian dari Gereja, untuk dapat menerima rahmat-Nya?

Fritzzon mengatakan pada 2Kor 13:4 dikatakan, "Karena sekalipun Ia telah disalibkan oleh karena kelemahan, namun Ia hidup karena kuasa Allah. Memang kami adalah lemah di dalam Dia, tetapi kami akan hidup bersamasama dengan Dia untuk kamu karena kuasa Allah." Ayat ini berkorelasi dengan 1Kor 12:22 yang berbicara mengenai kekuatan dan kelemahan tetapi tidak secara jelas mengatakan tentang apa yang dimaksud dengan kekuatan dan apa yang dimaksud dengan kelemahan. Satu hal yang dapat kita pelajari dari kata-kata Paulus ini adalah bahwa kita tidak dapat menguasai kekuatan kita tanpa mengakui kelemahan kita. ${ }^{34}$ Sekali lagi apabila penafsiran ini kita kaitkan dengan Gereja dan orang dengan disabilitas maka orang dengan disabilitas dapat dikatakan sebagai kelemahan yang ada di dalam Gereja. Akan tetapi orang dengan disabilitas tetap harus diakui keberadaannya. Dalam hal ini juga harus diperhatikan kebutuhannya terkhusus dari sisi rohani.

Selanjutnya Fritzson juga mengatakan orang dengan difabilitas yang memperoleh iman Kristiani disatukan dengan kesadaran akan cinta Tuhan dan belas kasih Yesus bagi orang sakit dan cacat, dan menemukan kekuatan dalam lindungan Tuhan. Kita yakin bahwa Tuhan mengasihi orang dengan disabilitas dan menjangkau semua kemungkinan untuk merespon kasih tersebut. Kita percaya bahwa setiap orang dengan difabilitas mempunyai kesempatan untuk menemukan kedamaian bersama Tuhan. ${ }^{35}$

Seluruh kehidupan adalah rahmat dari Tuhan dan merupakan bagian dari ciptaanNya. Dalam Kej 1:31 dikatakan bahwa setelah penciptaan seluruh surga dan bumi dan setiap bagian dari kehidupan, Allah melihat segala yang dijadikan-Nya itu, "sungguh amat baik". Allah tidak mengatakan apa yang diciptakannya itu "sempurna". Dengan nafas kehidupan, Allah mengaruniakan orang dengan keterbatasan dan kelemahan. Kita percaya bahwa manusia "diciptakan segambar dan serupa dengan Allah" (Kej :26), tetapi setiap orang tidak akan mampu merefleksikan atau menggambarkan Tuhan secara utuh.

\footnotetext{
${ }^{34}$ Bdk. Arne Fritzson and Samuel Kobe, Interpretating Disability A church of All and For All (Geneva: WCC Publication, 2004), hal. 12.

${ }^{35}$ Bdk. Ibid., hal. 67.
} 
Menjadi segambar dengan Allah tidak hanya berarti apa yang baik, tetapi selaras dengan kehendak Allah. ${ }^{36}$

Perjamuan terakhir yang dikenang dalam setiap perayaan Ekaristi, selalu mengenang kata-kata Yesus. Demi keselamatan dunia, Yesus rela untuk mengorbankan diri-Nya, "Ambillah dan makanlah, inilah tubuh-Ku yang $\mathrm{Ku}$ serahkan bagimu" (Mat 26:26). Kata "bagimu" dalam ayat ini mengacu pada seluruh umat manusia yang berarti Tubuh Yesus ini juga diberikan untuk umatnya yang menyandang disabilitas. Karena orang dengan retardasi mental juga merupakan orang dengan disabilitas maka mereka juga bisa mendapatkan Tubuh Tuhan yang diserahkan kepada manusia ini.

Kepada jemaat di Korintus, Paulus mengatakan, "Karena sama seperti tubuh itu satu dan anggota-anggotanya banyak, dan segala anggota itu, sekalipun banyak, merupakan satu tubuh" (1Kor 12:12). Dari ayat tersebut Fritzson merefleksikan bahwa retardasi mental adalah anggota Tubuh Mistik Kristus. Jika kehadiran orang dengan retardasi mental adalah menghadirkan anak-anak Allah yang tidak akan pernah menyinggung-Nya, hal ini dapat menjadi alasan yang cukup untuk membenarkan kehadiran mereka di dunia. Pembenaran ini tidak hanya persoalan untuk apa kehadiran mereka di dunia tetapi bahwa mereka juga memiliki panggilan untuk melakukan rencana Allah. Tidak ada manusia yang tidak penting. Setiap manusia memiliki tugasnya masingmasing di dunia, begitupun dengan orang dengan retardasi mental. Kinsela mengatakan meskipun orang dengan retardasi mental mungkin tidak dapat memiliki perkembangan fisik dan sosial, hidup pada tingkat sub-rasional dari rata-rata kemampuan mental manusia, orang dengan retardasi mental tetaplah manusia. Ia tetaplah seseorang yang memiliki hak asasi dan memiliki martabat. Ia adalah bagian dari umat manusia, tetaplah anak Allah dan individu yang tak ternilai. Mengapa? Karena orang dengan retardasi mental, tidak peduli seberapa keparahannya, tetaplah memiliki jiwa yang dibentuk secitra dan segambar dengan Allah. ${ }^{37}$

Yesus juga berkata, "Aku berkata kepadamu, sesungguhnya segala sesuatu yang kamu lakukan untuk salah seorang dari saudara-Ku yang paling hina ini, kamu telah melakukannya untuk Aku" (Mat 25:40). Ayat tersebut harus juga

\footnotetext{
${ }^{36}$ Bdk. Ibid., hal. 77.

${ }^{37}$ Bdk. Kinsela, Moral Orientation, hal. 92.
} 
ditempatkan bagi orang dengan retardasi mental dan siapapun yang sudah memberikan perhatian kepadanya.

Mengenai pelayanan imam Kinsela mengatakan pelayanan rohani imam untuk orang dengan retardasi mental dalam parokinya harus ditempatkan dalam kerangka membagikan rahmat pengorbanan Kristus untuk sebanyak mungkin orang. Oleh karena itu, orang dengan retardasi mental juga harus mendapatkan rahmat ilahi dari Kristus melalui sakramen-sakremen apabila hal tersebut memungkinkan. Penentuan kemungkinan penerimaan sakramen bagi orang dengan retardasi mental, dikaitkan dengan faktor teologis sebagai dasar dari sakramen-sakramen dan faktor psikologis dari orang dengan retardasi mental..$^{38}$

\section{Langkah Pastoral Penerimaan Komuni Suci Bagi Retardasi Mental}

Secara psikologis Retardasi mental memiliki empat tingkatan dengan tingkat kemampuan yang berbeda-beda. Tingkatan kemampuan ini mempengaruhi orang dengan retardasi mental dalam proses belajar, memahami sesuatu ataupun bersosialisasi. Apabila dilihat dari tingkatan kemampuan berpikir, penyandang retardasi mental yang dinilai mampu untuk memiliki pemahaman minimal yang dibutuhkan dalam menerima Komuni Suci adalah mild mental retardation (retardasi mental ringan) dan moderate mental retardation (retardasi mental sedang).

Menurut DSM IV retardasi mental ringan dengan IQ 50-70 memiliki kemampuan belajar akademik kira-kira sampai dengan usia kelas VI Sekolah Dasar. Bahkan kadang orang dengan retardasi mental ringan ini tidak dibedakan dengan individu tanpa retardasi mental. Mereka memang kesulitan dalam merencanakan sesuatu, membuat strategi, membuat prioritas, dan penyesuaian diri, tetapi pemahaman akan Tubuh dan Darah Kristus dapat dibuat lebih sederhana sesuai dengan kemampuan mereka. Penerima komuni pertama pada umumnya adalah anak-anak usia Sekolah Dasar. Pada usia ini, mereka dapat memiliki pemahaman minimal tentang Tubuh dan Darah Kristus. Retardasi mental ringan memiliki kemampuan berpikir kira - kira setara dengan usia Sekolah Dasar maka orang dengan retardasi mental ringan kemungkinan besar dapat memiliki pemahaman minimal ini. Walaupun demikian, pemahaman

38 Bdk. Ibid., hal. 94-95. 
tersebut kemungkinan dapat mereka miliki ketika usia belasan tahun.

Potensi akademik retardasi mental sedang setara dengan anak kelas 2 Sekolah Dasar. Oleh karena itu, pemahaman akan Tubuh dan Darah Kristus bagi orang dengan retardasi mental sedang memang agak sulit. Akan tetapi perlu dicoba terlebih dahulu karena mereka masih mampu mengerti dan berkomunikasi. Kemampuan untuk mengerti dan berkomunikasi ini dapat digunakan sebagai modal untuk mendampingi. Selain itu dari uraian pada bab II juga dikatakan bahwa mereka dapat memperoleh manfaat dari pelatihan atau ketrampilan tertentu. Oleh karena itu diandaikan mereka dapat diajak untuk berproses dalam memahami Tubuh dan Darah Kristus walaupun membutuhkan waktu yang panjang. Permasalahan yang muncul dari potensi akademik retardasi mental sedang adalah realitanya potensi akademik yang dimiliki sulit untuk bisa memahami sesuatu.

Penerimaan komuni mau tidak mau membutuhkan pemahaman akan apa yang diterima walaupun sangat sederhana. Pemahaman sederhana ini sangat mungkin dimiliki oleh retardasi mental ringan sehingga kesempatan untuk menerima komuni dapat diberikan kepada mereka. Lalu bagaimana dengan retardasi mental sedang? Orang dengan retardasi mental sedang dapat diajarkan secara berulang - ulang tentang tata cara menerima dan memakan hosti. Pembelajaran ini pasti dapat diterima dan pada akhirnya mereka dapat melakukannya sendiri. Orang dengan retardasi mental sedang hanya sebatas tahu cara menerima dan memakan hosti selebihnya mereka tidak mengerti tentang makna hosti sebagai Tubuh dan Darah Kristus. Retardasi mental sedang mungkin hanya akan berpikir bahwa hosti yang mereka terima adalah makanan yang dimakan.

Akan tetapi, kita tidak boleh tergesa-gesa dalam memutuskan seorang retardasi mental tidak dapat menerima komuni. Permasalahan yang dihadapi oleh orang dengan retardasi mental adalah fungsi adaptif maka perlu diperhatikan mengenai kemampuan mereka beradaptasi dengan situasi Misa dan penerimaan komuni. Ketika orang dengan retardasi mental ini mampu beradaptasi dengan situasi Misa dan penerimaan komuni, hendaknya hal tersebut menjadi pertimbangan karena apa yang dicapai tersebut merupakan usaha yang besar dari mereka untuk dapat menerima Komuni. Penerimaan Komuni bagi retardasi mental sedang tidak dapat disamaratakan. Kemampuan masing-masing pribadi berbeda. Kemampuan ini dapat dievaluasi bersama antara orangtua, pendamping dan Pastor Paroki. Sedangkan untuk retardasi mental parah dan sangat parah perlu keterbukaan hati bahwa komuni suci 
memang sulit untuk diberikan. Secara psikologis, pendampingan komuni bagi retardasi mental ini terasa sulit. Oleh karena itu, Pastor Paroki, pendamping dan orangtua harus memiliki empati dan keseriusan yang lebih besar untuk mendampingi. Mereka juga harus siap apabila pendampingan yang dilakukan gagal.

Seperti pada awal pembahasan karena keinginan Gereja untuk memberikan komuni suci kepada retardasi mental ini sangat besar maka terkadang komuni suci ini diberikan kepada semuanya tanpa melihat kemampuan pribadi tersebut untuk menerimanya. Ketidakmampuan orang dengan retardasi mental untuk menerima dan memahami menyebabkan hosti tidak dapat diterima dengan baik atau pribadi tersebut seperti dipaksa untuk dapat menerima dan menelan. Oleh karena itu penulis mengusulkan beberapa hal yang dapat digunakan sebagai panduan sederhana untuk pendampingan penerimaan komuni suci bagi orang dengan retardasi mental. Orang dengan retardasi mental tentunya tidak bisa memenuhi standar yang dipergunakan bagi para calon penerima komuni pertama lainnya. Oleh karena itu ada beberapa kelonggaran yang diberikan kepada mereka.

Pertama, materi pengajaran. Materi dapat diberikan seperti menjelaskan secara bertahap bahwa hosti bukanlah roti biasa dan harus dihormati, hosti harus dimakan dan ditelan dengan baik, mengajak mereka untuk tenang ketika mengikuti misa. Untuk retardasi mental ringan dapat diajarkan untuk menghafal doa-doa pokok bahkan pengakuan dosa. Materi pengajaran ini dapat juga melalui video agar mereka memiliki bayangan secara visual, misalnya untuk menunjukkan konsekrasi. Perlu juga dilakukan praktek menerima komuni dengan menggunakan hosti yang belum dikonsekrasi sehingga mereka dapat lebih mengerti tata cara penerimaannya. Dalam pendampingan penerimaan komuni pertama juga harus diperhatikan materi-materi yang digunakan agar orang dengan retardasi mental dapat mudah memahami.

Orang dengan retardasi mental mempunyai dorongan dan mempunyai hubungan dengan orang-orang berbagi untuk doa dan iman. Mereka juga memiliki suatu perasaan yang diungkapkan melalui perilaku. Kadang orangorang ini tidak dapat mengatakan mengenai pemahaman mereka tentang roti biasa dengan hosti. Akan tetapi mereka dapat mengenali melalui cara mereka sendiri yang dapat diungkapkan melalui mata, isyarat ataupun kualitas dalam diamnya. Dalam diam, mereka dapat merasakan kehadiran Tuhan melalui Komuni yang diterima. Keinginan seseorang untuk dapat menerima Komuni 
Suci hendaknya dapat diwadahi. ${ }^{39}$

Kedua, model pendampingan. Persiapan penerimaan komuni suci bagi retardasi mental harus melibatkan orangtua secara aktif. Keikutsertaan orangtua dalam pendampingan diperlukan agar orangtua mengetahui apa yang diajarkan sehingga di rumah pun orangtua dapat memberikan pendampingan. Orangtua setiap saat dapat memberikan pengertian tentang komuni setiap saat mengajak mereka berdoa. Dengan demikian pendampingan terus berkelanjutan. Model pembelajaran ini diharapkan semakin membantu proses belajar orang dengan retardasi mental untuk memiliki pemahaman sederhana tentang Komuni Suci. Orangtualah yang tahu apakah hostiakan dilepe $^{40}$ atau tidak, maka yang dibekali katekese adalah orangtuanya. Pertemuan dengan orang dengan retardasi mental dan orangtuanya tetap dilakukan. Pertemuan hanya dilakukan beberapa kali sebagai sarana pertemuan untuk saling menguatkan. Orang dengan retardasi mental memerlukan orang lain dan berada dalam hubungan yang penuh kasih untuk membantu pertumbuhan iman yang dimiliki. Dengan cara ini orang dengan retardasi mental dapat mengembangkan dan menemukan kriteria dalam menerima Komuni Suci, antara lain: (1) relasi dengan orang beriman dan merayakan liturgi. (2) memiliki rasa hormat dan bagaimana bersikap dalam liturgi, dan (3) keinginan untuk menerima Komuni Suci. ${ }^{41}$

Ketiga, keputusan menerima komuni suci. Tahapan terakhir dari persiapan Komuni Pertama bagi retardasi mental ini adalah memutuskan apakah orang dengan retardasi mental tersebut dapat menerima komuni. Keputusan untuk menentukan apakah orang dengan retardasi mental dapat menerima komuni suci atau tidak adalah hasil pertimbangan bersama antara pastor paroki, katekis dan orangtua. Masing-masing pihak, terutama orangtua, harus secara terbuka mengungkapkan pendapatnya tentang pemahaman yang dimiliki calon penerima komuni pertama. Menurut pandangan penulis, persyaratan minimal bagi orang dengan retardasi mental adalah Pertama, mereka mengerti tata cara menerima komuni dan menghormati hosti dengan memakan dan menelannya. Kedua, mereka dapat mengikuti Ekaristi. Ketiga, mereka mengerti ketika diajak ke Gereja dan berdoa. Persyaratan tersebut terlihat sangat minimal. Akan tetapi apabila hal tersebut dapat dicapai, bagi orang dengan retardasi mental sedang

${ }^{39}$ Bdk. Bernardin, "The Sacraments", hal. 78.

${ }^{40}$ Bahasa jawa: dikeluarkan lagi dari mulut.

${ }^{41}$ Bdk. Marry Therese Harrington, "The Right of Person with Developmental Disabilities to Receive The Sacraments", New Theology Review 7, no. 3 (Agustus 1994). 
merupakan usaha yang sangat besar. Apabila keputusan yang diambil adalah bahwa orang dengan retardasi mental tersebut dapat menerima Komuni Pertama, bukan berarti proses pendampingan selesai. Orangtua dan keluarga yang setiap hari bersamanya harus terus mendampingi mereka dalam hal iman. Dukungan dari keluarga juga umat akan membantunya untuk dapat selalu mengungkapkan rasa syukur kepada Allah melalui doa dan Gereja.

\section{Solusi Pastoral Bagi Orang dengan Retardasi Mental Yang Tidak Dapat Menerima Komuni Suci}

Membuat keputusan bersama apakah orang dengan retardasi mental dapat menerima Komuni atau tidak, tidaklah mudah. Keputusan yang dibuat akan terasa mudah apabila keputusan yang diperoleh adalah dapat menerima. Tetapi keputusan akan sulit dikatakan apabila hasilnya adalah tidak dapat menerima. Keputusan untuk tidak dapat menerima ini tentunya berat bagi Pastor Paroki, Katekis, terlebih orangtua setelah proses yang dilakukan. Hal inilah yang menjadi alasan mengapa sedari awal para pihak, terutama orangtua, harus memahami persyaratan minimal yang hendaknya dipenuhi dan juga kemungkinan-kemungkinan yang dapat terjadi. Orangtua tidak perlu berkecil hati apabila anaknya tidak menerima Komuni Suci. Pastor Paroki harus memiliki kepekaan akan hal ini sehingga dapat membesarkan hati orangtua.

Walaupun anaknya tidak dapat menerima Komuni Suci, orangtua didorong untuk tetap mengajak anaknya mencintai Yesus dalam doa dan hidup menggereja. Kasih Allah menjangkau setiap pribadi, termasuk orang yang paling lemah dan tidak mampu mengenalnya melalui Komuni Suci. Gereja harus memberikan solusi lain sebagai bentuk perhatian kepada mereka yang lemah ini. Satu hal yang dapat dilakukan untuk menjangkau pribadi yang tidak mampu menerima Komuni Suci sekaligus sebagai bentuk perhatian dan dukungan kepada orangtua adalah dengan cara memberikan berkat tanda salib di dahi oleh Imam.

Dalam Misa, pemberian berkat di dahi ini biasanya dilakukan setelah selesai penerimaan komuni. Berkat di dahi ini merupakan kesempatan untuk merengkuh mereka yang belum menerima komuni. Dalam Ul 6:4-8 tertulis:

Kasihilah TUHAN, Allahmu, dengan segenap hatimu dan dengan segenap jiwamu dan dengan segenap kekuatanmu. Apa yang kuperintahkankepadamu pada hari ini haruslah engkau perhatikan, haruslah engkau mengajarkannya berulang-ulang kepada anak-anakmu dan membicarakannya apabila engkau duduk di rumahmu, apabila engkau sedang dalam perjalanan, apabila 
engkau berbaring dan apabila engkau bangun. Haruslah juga engkau mengikatkannya sebagai tanda pada tanganmu dan haruslah itu menjadi lambang di dahimu...

Dalam tradisi bangsa Yahudi, pelaksanaan perintah tersebut dilakukan dengan memakai tefilin yaitu semacam kotak hitam yang berisi naskah Alkitab, yang mereka ikatkan di dahi mereka. ${ }^{42}$ Sedangkan dalam Yeh 9:4 dinyatakan, “Berjalanlah dari tengah-tengah kota, yaitu Yerusalem dan tulislah huruf T pada dahi orang-orang yang berkeluh kesah karena segala perbuatan-perbuatan keji yang dilakukan di sana". Dalam ayat selanjutnya dinyatakan bahwa orang yang memakai tanda $\mathrm{T}$ di dahi jangan disinggung, sedangkan yang tidak memakai tanda $\mathrm{T}$ akan dimusnahkan. Tanda $\mathrm{T}$ dalam perikop ini menjadi tanda pelindung agar terbebas dari hal yang buruk. Pelaksanaan penggunaan tanda T dalam ayat tersebut, pada konteks saat ini, dapat diinterpetasikan dengan memberikan tanda salib di dahi.

Tanda salib yang diberikan di dahi tidak hanya sebagai rutinitas dalam Misa. Selain untuk merengkuh umat yang belum menerima komuni, tanda salib di dahi ini juga memiliki makna tersendiri. Berkat tanda salib yang kita terima di dahi menjadi tanda bahwa kita adalah milik Tuhan Yesus dan kita adalah anak-anak Tuhan. Berkat tanda salib yang kita terima di dahi juga merupakan tanda perlindungan yang kita terima dari Tuhan Yesus Kristus yang telah mengalahkan kuasa kejahatan dengan salib-Nya. ${ }^{43}$ Dari makna tersebut, tanda salib di dahi juga merupakan tanda keselamatan yang diberikan Allah bagi manusia.

Pemberian tanda salib di dahi diharapkan menjadi solusi yang dapat bagi orang dengan retardasi mental yang tidak mampu menerima Komuni Suci. Inilah bentuk perhatian Gereja kepada pribadi-pribadi yang memiliki keterbatasan. Bagi para orangtua solusi ini diharapkan dapat membuat mereka merasa tidak sendiri. Perjuangan orangtua dalam mengasuh dan mendampingi iman anaknya tidak akan terhenti hanya karena anaknya tidak dapat menerima komuni. Orangtua orang dengan retardasi mental akan terus bersama anaknya, mensyukuri anugerah Allah tersebut dengan caranya sendiri. Perhatian minimal yaitu pemberian berkat tanda salib di dahi oleh imam menjadi cara se-

${ }^{42}$ Diunduh dari https://www.katolisitas.org/dalamnya-makna-tanda-salib/ , 28 Agustus 2020.

${ }^{43}$ Bdk. E. Martasudjito Pr, Yuk Bersama-sama Merayakan Ekaristi (Yogyakarta: Kanisius, 2006), hal. 20-21. 
derhana yang dapat dilakukan Gereja untuk bersama-sama dengan orangtua menjaga iman orang dengan retardasi mental. Demikian pula dengan rahmat kasih Allah melalui berkat tanda salib di dahi, akan bekerja dengan cara-Nya sendiri bagi orang dengan retardasi mental walaupun tidak bisa menerima Komuni Suci.

\section{KESIMPULAN}

Dari penelitian ini ada beberapa hal yang sebaiknya dimengerti oleh orangtua dari orang dengan retardasi mental, pastor paroki, katekis dan umat pada umumnya sebagai pertimbangan saat memberikan pelayanan rohani bagi orang dengan retardasi mental terutama tentang Komuni Suci. Pertama, Gereja tidak boleh tergesa-gesa dalam menentukan apakah orang dengan retardasi mental dapat menerima komuni atau tidak. Untuk menentukan boleh menerima komuni atau tidak, harus terlebih dahulu dilihat kondisi orang dengan retardasi mental tersebut. Salah satu cara untuk melihat kondisi ini adalah dengan wawancara. Penerimaan Komuni Suci bagi orang dengan retardasi mental menempatkan orang dengan retardasi mental ringan (mild mental retardation) dan retardasi mental sedang (moderate mental retardation) sebagai tingkatan retardasi mental yang memiliki kemungkinan untuk dapat menerima Komuni Suci.

Secara yuridis dikatakan bahwa untuk dapat menerima Komuni seseorang harus memiliki pemahaman akan misteri Kristus (bdk. KHK 914). Pemahaman ini juga diterapkan bagi orang dengan retardasi mental tetapi pemahaman yang dimiliki adalah pemahaman yang sederhana. Dari sisi psikologis retardasi mental ringan mempunyai kemungkinan yang lebih besar untuk memahami Tubuh Kristus, Ekaristi dan doa daripada retardasi mental sedang. Akan tetapi tidak ada salahnya untuk mencoba memberikan pengajaran persiapan komuni pertama bagi retardasi mental sedang.

Orang dengan retardasi mental membutuhkan cara pengajaran yang berbeda. Maka perlu dipersiapkan materi dan proses pendampingan yang sesuai. Pendampingan ini melibatkan pastor paroki, katekis dan orangtuanya. Kerjasama antara pastor paroki, katekis dan orangtua menjadi faktor yang sangat penting dalam memutuskan, apakah orang dengan retardasi mental dapat menerima Komuni Suci atau tidak. Masing-masing pihak akan berproses bersama sehingga dapat saling memberikan masukan atas perkembangan yang dialami orang dengan retardasi mental dalam mempersiapkan Komuni Pertama. 
Pemahaman mengenai difabilitas merupakan bagian pendidikan yang penting terutama untuk para imam. Ada anggapan bahwa para imam kurang memahami tentang difabilitas. Jika dalam hirarki Gereja tidak dibahas mengenai hal ini maka perhatian terhadap difabel tidak akan masuk dalam perencanaan. Perhatian ini akan semakin terasa bijaksana apabila kesadaran untuk memberikan perhatian pada difabel ini dibangun dalam setiap tingkatan yang ada di keuskupan. Melalui setiap tingkatan ini, perhatian akan lebih mudah diberikan. Memberikan perhatian kepada difabel tidak hanya berbicara mengenai keadilan tetapi juga tentang kebersamaan dan persahabatan. ${ }^{44}$ Dengan demikian pastoral kepada UBK menjadi tanggung jawab bersama seluruh umat dengan para imam yang diharapkan dapat menjadi motor penggeraknya.

Harus ada standarisasi yang ditentukan untuk membantu memutuskan apakah orang dengan retardasi mental dapat menerima Komuni atau tidak. Standarisasi ini bukan digunakan untuk membatasi mereka. Standarisasi digunakan untuk melihat bahwa orang dengan retardasi mental memang memiliki pemahaman sederhana tentang Tubuh Kristus, Ekaristi dan doa. Selain itu, dengan standarisasi ini, orang dengan retardasi mental tidak terkesan "dipaksakan" dalam menerima komuni. Standarisasi yang ada harus dipahami bersama sedari awal sehingga apabila keputusan yang diambil adalah tidak dapat menerima komuni, masing-masing pihak, terutama orangtua, dapat memahami. Standarisasi paling sederhana yang dapat diterapkan adalah orang dengan retardasi mental tersebut dapat menerima hosti dengan baik, memakan dan menelannya. Keterbukaan Gereja untuk memberikan perhatian bagi difabel dan umat berkebutuhan khusus dengan memberikan pelayanan sakramen inisiasi menunjukkan bahwa mereka juga bagian dari Gereja yang harus diperhatikan. Kesempatan yang diberikan oleh Gereja, khususnya untuk orang dengan retardasi mental dalam menerima komuni merupakan bentuk perhatian bagi iman mereka. Apapun bentuk perhatian yang diberikan terlebih penerimaan komuni sekaligus sebagai bentuk empati dan dukungan bagi orangtua dan keluarganya. Orangtua dari orang dengan retardasi mental tentu memiliki pergulatannya sendiri dalam mendampingi anaknya. Perhatian Gereja ini paling tidak mengingatkan mereka bahwa mereka tidak sendiri. Gereja menjadi tempat dimana kasih Allah dibagikan tidak hanya bagi mereka

${ }^{44}$ Anne Renggli, dkk., "People With Disabilities : A Study Of Ministry", Origins: CNS Documentary Service 24, no.13 (8 September 1994), hal. 235. 
yang dapat dengan mudah memahami keberadaan-Nya tetapi juga untuk mereka yang sulit untuk memahaminya.

\section{DAFTAR KEPUSTAKAAN}

American Psyciatric Association, Diagnostic and Statistical Manual of Mental Disorder IV. Washington: American Psychiatric Press Inc, 1994.

American Psyciatric Association, Diagnostic and Statistical Manual of Mental Disorder V. Washington: American Psychiatric Publishing, 2013.

Fritzson, Arne and Samuel Kobe, Interpretating Disability A church of All and For All. Geneva: WCC Publication, 2004.

Kinsela, Noel A., B.A, S.T.L, Ph. D, Moral Orientation of The Mentally Retarded. Roma: Pontificia Universita Laternense, 1967.

Konferensi Wali Gereja Indonesia, Kitab Hukum Kanonik. Bogor: Grafika Mardi Yuana, 2012.

Konferensi Wali Gereja Indonesia, Pedoman Umum Misale Romanum terjemahan Institutio Generalis Missalis Romani. Ende: Penerbit Nusa Indah, 2002.

Konferensi Wali Gereja Indonesia, Dokumen Konsili Vatikan II, terj. R. Hardawiryana. Dokumentasi dan Penerangan KWI. Jakarta: Obor, 1993.

Martasudjito, E, Yuk Bersama-sama Merayakan Ekaristi. Yogyakarta: Kanisius, 2006.

Martasudjita, E, Sakramen-Sakramen Gereja. Kanisius: Yogyakarta, 2003.

Martasudjita, E., Ekaristi. Tinjauan Teologis, Liturgis dan Pastoral. Yogyakarta:

Penerbit Kanisius, 2005.

M Droste"dc" Gloria, Bernadeta, Quam Singulari. Ende: Yayasan Pustaka Nusatama, 2011.

Semiun, Yustinus, Kesehatan Mental 2. Jogjakarta: Kanisius, 2006.

Wenar, Charles, Patricia Kerig, Developmental Psychopathology From Infancy

Through Andolescence. Fourth Edition. New York: Mc Graw-Hill Higher Education, 2000.

Agung Nugroho, R.B.E., “UBK Bagian Gereja”, Hidup 70 (3 Juli 2016).

Bernardin, Joseph, "The Sacraments and Developmentally Disabled Person", Origins: NC Documentary Service 15, no. 47 (8 Mei 1986).

Renggli, Anne, "People With Disabilities : A Study Of Ministry", Origins: CNS Documentary Service 24, no. 13 (8 September 1994).

Therese Harrington, Marry, "The Right of Person with Developmental Disabilities to Receive The Sacraments", New Theology Review 7, no. 3 (Agustus 1994). 
Vinay, Samuel, “God, Humanity and Disability”, Transformation 15, no. 4 (1998). ChrisSudgen, "Biblical and Theological Reflections on Disability", Transformation 15, no. 4 (1998). 